\title{
The Way of Recruiting Students in Digital Media Art Major in Colleges*
}

\author{
Juanjuan Dong \\ East China University of Science and Technology \\ Shanghai, China
}

\author{
Zhengqing Jiang \\ East China University of Science and Technology \\ Shanghai, China
}

\begin{abstract}
In 2012, digital media art formally became the second-level subject under the design of science and It's professional construction has developed rapidly. However, the phenomenon of mismatch between competency and professional training objectives is becoming increasingly prominent for the students who are enrolled in the way of "art college entrance examination". This article takes the origin and evolution of the "art college entrance examination" as the entry point, and compares and analyzes the enrollment methods of digital media arts in different types of universities at home and abroad, and clarifies the logic of the selection of intrinsic ability behind the entrance exams. Based on the idea of initiating an elaboration, I hope that this article can trigger the discussion of experts and scholars and explore the direction for the reform of the enrollment methods for digital media art majors in Chinese universities.
\end{abstract}

Keywords-training objectives; ability of selection; enrollment methods; digital media art

\section{INTRODUCTION}

At the beginning of the 21st century, the universities represented by Communication University of China began to actively explore the training model of digital media arts (hereinafter referred to as digital media) professionals. In April 2018 , in order to promote the close integration of talent training with regional economic and social development, industrial development and industry development, the establishment of the national standards for majors about teaching quality in animation, digital media art and digital media technology by the industry department (association) was promoted by ministry of education. The standard clarifies the training objectives of the digital media major: To train and master the basic knowledge, basic theories and methods of special effects creation, film and television post production, network video production, internet development, network interactive design and the application of related tools[1].It aims at training the innovative professionals in media and cultural industry related fields engaged in film and television network media planning, creation, production, dissemination, operation or management [2]. In addition to the ability to master color, sketch, art and art design, students majoring in digital media should also have the digital skills of computer technology and image processing. And it has become a consensus of industry and education to train the complex talents of art and technology. But in the actual teaching, especially the students majoring in digital media in the comprehensive university, their ability does not match with the training goal prominently. Taking my university as an example, under the same conditions of teachers and curriculum, the students of digital media art major in English and computer programming are in serious situation. In the background of the Ministry of Education's promotion of independent enrollment, the gap between students' ability and the goal of professional training has caused us to discuss the ways of recruiting students in digital media major.

\section{THE ORIGIN OF RECRUITING STUDENTS FOR DIGITAL} MEDIA MAJOR IN COLLEGES AND UNIVERSITIES IN CHINA

According to the subject catalogue issued by the Ministry of Education in 2012, the subject of digital media belongs to the category of art and is a secondary subject of design. Because its student origin attribute is the art examinees, the way of recruiting students has continued the pattern of "entrance examination of arts" ,and the approximate process is: examinees take part in the art examination of their province (the main content is sketch, color), and only after passing the examination can they participate in the art school examination organized by the university itself(the main content is sketch, color, literary sketch), and then make an excellent selection with its achievements and the grade of the entrance examination(Cancel the division of students into different tracks in high school) after conversion. In order to clarify the origin and development of recruiting students system, this paper summarizes the way of art recruiting students by collecting and arranging relevant data ("Fig. 1").

*Fund program: The funding project for Shanghai Summit Discipline in Design of IV category-study on the visual comfort level of the stereo image design based on the virtual reality devices- DB17024. Supported by Shanghai Summit Discipline in Design. The construction project of the digital media art new specialty of East China University of Science and TechnologyYZ0129106. 


\begin{tabular}{|c|c|c|c|c|}
\hline 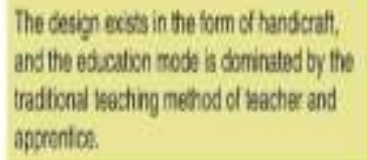 & $\begin{array}{l}\text { The cosisterce sistes of } \\
\text { university pint exemination and } \\
\text { indidual entence exaninaton }\end{array}$ & 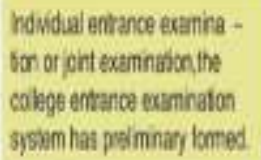 & 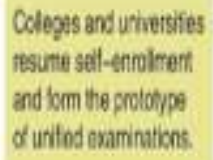 &  \\
\hline
\end{tabular}

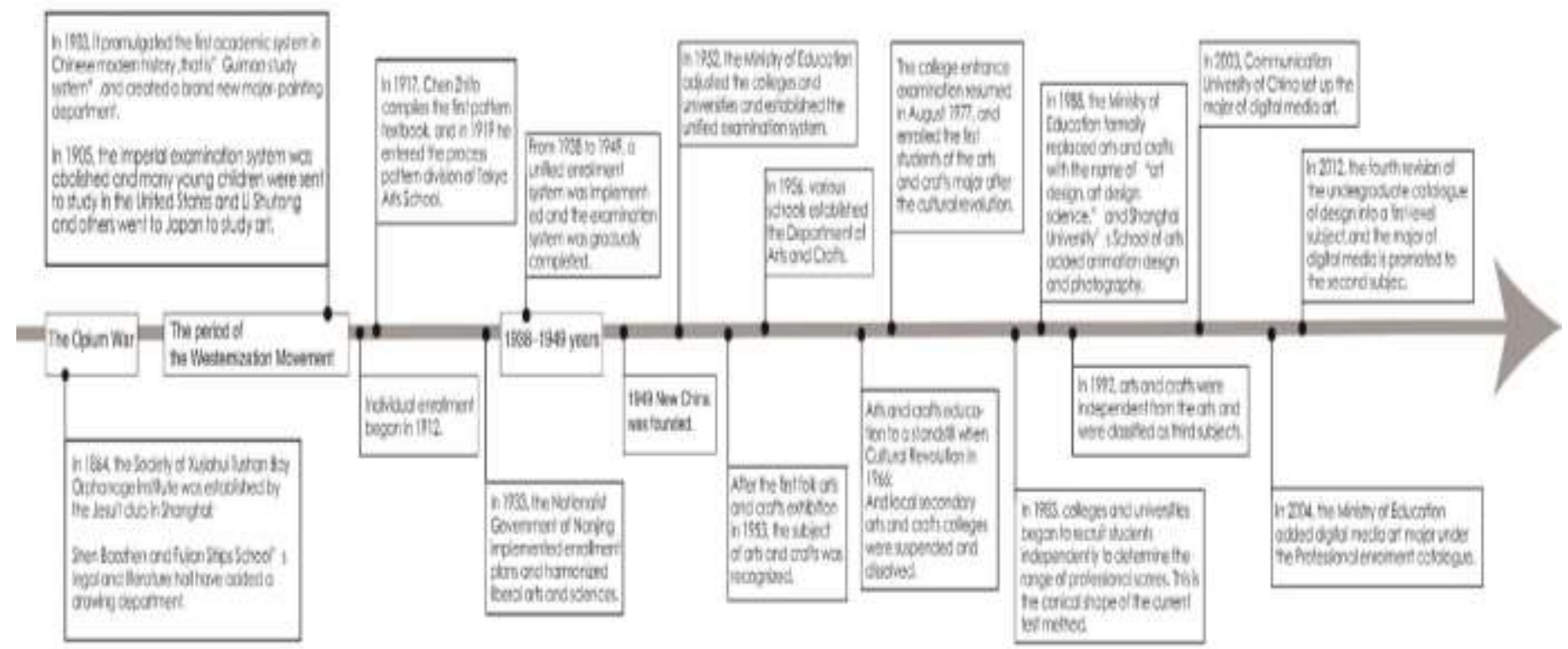

Fig. 1. The evolution of recruiting students system of Arts in Chinese Colleges and Universities.

From "Fig. 1", we can see that the design subject based on digital media art has evolved from handicraft, graphics, arts-crafts and art design. And the training mode is from the teacher's apprenticeship to small school education [3]. The initial selection standard is to select suitable apprentices through communication between teachers and students. In essence, the students' professional practical ability is evaluated by interview, and the students' professional skills and potentials are emphasized, and the subjectivity is very strong. With the development of society, the demand for professionals in the industry has increased, and schools have become large-scale. The assessment of master and apprentice interviews was not efficient enough to meet the large-scale recruitment of students, which generated the form of art recruiting students. The development of art education in France, which has a profound influence on Chinese art education, also proves that it is inspired by trade unions, and later developed into a recruiting students way based on college and in cooperation with academicians. All follow the industry to guide academic research, and then academic research promoted to knowledge theory system, and further promotes the law of industrial development.

In the Republic of China, with the introduction of western education mode, the main body of University was diversified. The independent recruiting students was rose and the system of recruiting students is loose and flexible as a whole, that the school may enroll the corresponding student according to its own university characteristic[4]. The contents of the examination draw lessons from the traditional European academic school, that is, by copying the gypsum image, to examine the examinee's modeling and realistic ability. The highly flexible autonomy of the school has resulted in the possibility of being admitted to colleges and universities in the face of poor cultural standards but strong professional skills. This is partly due to the demand and technical conditions of the industry for hand-drawn skills, practical ability is the most important concern and this stage set the training goal for students with painting ability. At the same time, in view of the low level of education as a whole at that time, the requirements of cultural mastery were properly lowered. After the founding of the People's Republic of China, in view of the large number of colleges and different ways of training, the state regulated schools. The private university was transformed into a public university, the Education Bureau unified the standard of recruiting students, and the recruitment students of the arts were also standardized and institutionalized. Gradually, a system of "art entrance examination" is formed-that is, students are divided into arts and non-artistic arts through art plus examinations, and arts students are recruiting students to lower the examination requirements for cultural classes. After continuous development, the art of the entrance examination gradually modeled and stereotyped. With the development of society, the comprehensive implementation of nine-year compulsory education and the "expansion of 
enrollment" in colleges and universities, the university has transformed from elite education to mass education, but the examination content has been solidified into sketch, and the colorful "entrance examination of arts" has become anachronistic. Gradually losing the effectiveness of talent selection, it has become a shortcut for a small number of candidates: some students who do not perform well in cultural classes undergo surprise training for a few months before the examination, so that they can be admitted to the desired universities. The original intention is not to truly love art, but because of the special treatment of art students, such utilitarian idea causes the phenomenon that the quality of students cannot meet the goal of professional training.

Although the art recruiting students mode has different in different times, its essence has not changed, that is to select the students who fit the industry at that time and have the relevant academic ability, which is one of the important reasons that the Ministry of Education endows the independent recruiting students right to the university. When thinking about the recruiting students mode of digital media major, colleges and universities must recognize the development needs of society, industry and trade, and have insight into what kind of talents they need to have. However, due to the dynamic characteristics of social industry and academic research, a large number of social investigations are needed to clarify the most suitable ability selection system. Limited to the length of the article, this article explore a new way to study the recruiting students mode, through the study of representative colleges and universities at home and abroad to recruit students, backward to find the inherent ability system which the media students should possess.

\section{ANALYSIS ON RECRUITING STUDENTS SYSTEM OF DigitAl MEDIA MAJOR IN COLLEGES AND UNIVERSITIES AT HOME AND ABROAD}

The digital media art major has been established and developed rapidly in the United States, and the recruiting students method of accurate positioning of talent in Colleges and universities plays an important role in this. Take Yale University, where the art design major is in the top five in the United States, and Harvard University, which has the elitism of recruiting students as an example. This paper discusses the recruiting students system of digital media arts major in these two universities (see "Table I") to explore the scientific selection system behind it.

TABLE I. YALE UNIVERSITY AND HARVARD UNIVERSITY RECRUITING METHODS FOR MEDIA MAJORS

\begin{tabular}{|c|c|c|c|}
\hline \multirow{2}{*}{ University } & \multirow{2}{*}{$\begin{array}{l}\text { Colleges and } \\
\text { universities }\end{array}$} & \multicolumn{2}{|c|}{ Enrollment pattern difference } \\
\hline & & same & emphasis \\
\hline $\begin{array}{c}\text { Yale } \\
\text { University }\end{array}$ & $\begin{array}{c}\text { School of } \\
\text { Art }\end{array}$ & \multirow{2}{*}{$\begin{array}{l}\text { The recruiting students model } \\
\text { is to apply for the application, } \\
\text { submit a high school } \\
\text { transcript,recommendation } \\
\text { letter, recommendation letter, } \\
\text { work collection, ACT or SAT } \\
\text { standard test results and other } \\
\text { related materials that can } \\
\text { prove the applicant's ability, } \\
\text { and the interview can be } \\
\text { selected by telephone inter- } \\
\text { view. }\end{array}$} & $\begin{array}{l}\text { Focus on the students' creative } \\
\text { design ability, including graphic } \\
\text { design, multimedia design } \\
\text { practice ability. }\end{array}$ \\
\hline $\begin{array}{l}\text { Harvard } \\
\text { University }\end{array}$ & $\begin{array}{l}\text { School of } \\
\text { Design }\end{array}$ & & $\begin{array}{l}\text { Focus on the students' sense of } \\
\text { space design, for new materials } \\
\text { and new technology applica- } \\
\text { tions, cognition. And extracurric- } \\
\text { ular activity ability and personal- } \\
\text { ity,comprehensive investigation. }\end{array}$ \\
\hline
\end{tabular}

${ }^{\text {a. }}$ Sample of a Table footnote. (Table footnote)

American students are required to submit relevant materials to apply for recruitment students to review and evaluate the application materials(high school transcripts, letters of recommendation, self-recommendation letters, ACT / SAT standard test scores and other certificates), according to the application materials to conduct a comprehensive evaluation of applicants to decide whether or not to admit[5].High school report card, recommendation letter and self-recommendation book are mainly about the investigation of students' comprehensive quality and ability, and the collection of works accounts for about $60 \%$.Each college will make a proposition on the collection every year, and will examine the authenticity of the collection submitted by the students through interviews. The recruiting students office will score according to the standards of the teachers of the department of colleges and universities, and pay attention to the examination of the students' professional potential and innovation ability. SAT / ACT adopts standardized test as our country's college entrance examination, but the examinee can take many times in a year, and take the highest one as the student's final result, so as to avoid the influence of accidental factors on the student's achievement as far as possible[6]. The purpose of the examination is to investigate the basic academic ability of the examinee, accounting for about $20 \%$ of the total score. In addition, the interview mainly describes the content of the collection of works, specifically assesses the students' ability to communicate and communicate, the ability to master professional knowledge and the potential for professional development is about $20 \%$.Of course, the United States has a high degree of recruiting students autonomy, and the specific 
percentage of scores of different colleges will be relatively different. Through expert interviews and literature search and other relevant research, the author tries to summarize the ability selection system of digital media majors in the United States as shown in "Fig. 3". It can be seen that the American digital media art specialty focuses on the examination of students' professional skills and innovation ability through the relatively individualized and flexible way of collection of works. According to the ability selection system in the United States, we can know the ability structure of the digital media major students, and compare it with the art entrance examination form adopted by the digital media major in our country to obtain the ability selection model of the domestic universities and colleges as shown in "Fig. 3".



Fig. 2. The ability selection system of Digital Media majors in American Colleges and Universities.

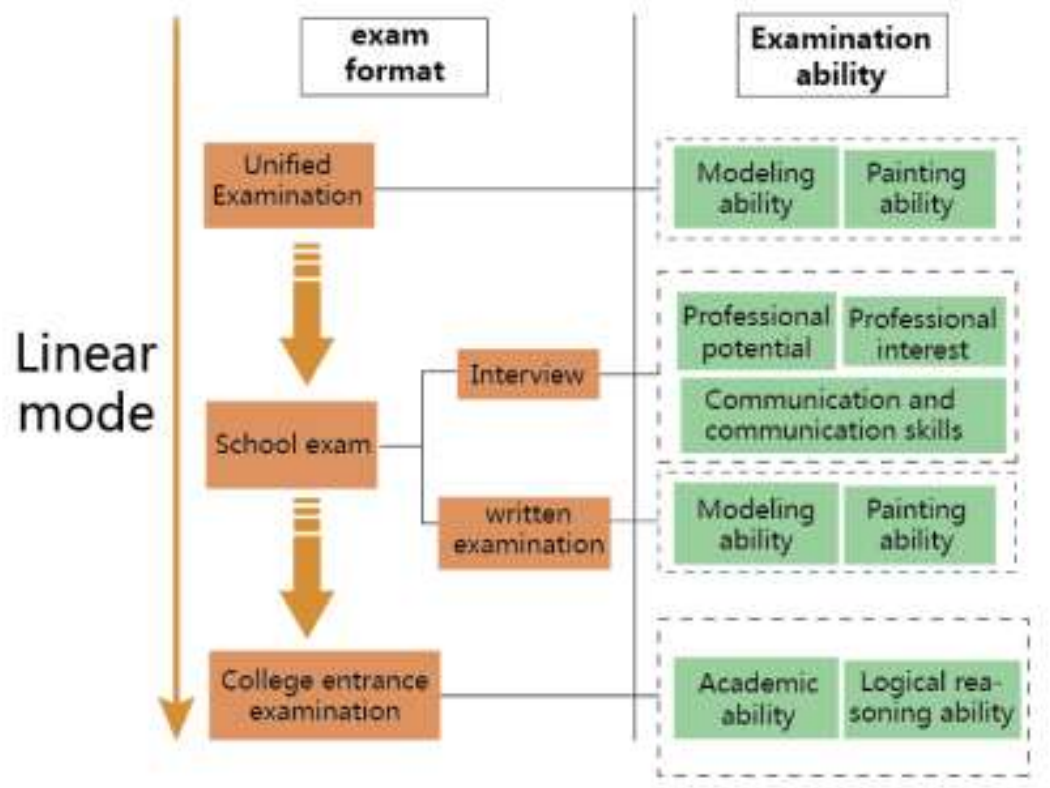

Fig. 3. The Selection Model of Digital Media Major ability in China's Colleges and Universities.

Compared with the recruiting students system between China and the United States, the recruiting students mode in the United States as a whole is more liberal and flexible, while the recruiting students mode in our country is a linear process model, and only after the United States has passed the examination can it be qualified to be a arts examinee. The examination in the United States is to aggregate all the materials together to select and assess the whole. There is no screening standard in the initial stage, and some candidates have poor cultural and academic ability, but their professional skills and innovative ability are strong, and they still have the opportunity to be admitted. According to the ability selection system of our country, the provincial unified examination is the threshold that the examinee of digital media major must pass. The purpose of the examination is to screen the students with the ability of modeling in the initial stage, and if the ability of modeling is not passed, it means that the scope of the recruitment students for the art major has become narrower. Stop a group of people with professional potential outside the door. From the point of view of self-competence, the recruiting students of digital media in the United States attaches importance to the quality of personal materials (portfolio), to the professional skills and innovation potential of candidates; Our country attaches 
great importance to modeling ability, even repeated examination of unified examination and school examination.

In view of the above deficiency, some colleges and universities in our country have made the reform exploration under the big system frame. After investigation, the author selected four representative universities, including Communication University of China, Tongji University, Jiangnan University and Beijing University of posts and Telecommunications, as the research samples, and their recruiting students system is shown in "Table II".

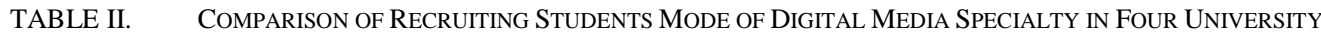

\begin{tabular}{|c|c|c|c|}
\hline $\begin{array}{l}\text { exam } \\
\text { format }\end{array}$ & $\begin{array}{l}\text { University } \\
\text { name }\end{array}$ & $\begin{array}{c}\text { Investigation } \\
\text { content }\end{array}$ & $\begin{array}{c}\text { Admission require- } \\
\text { ments }\end{array}$ \\
\hline \multirow[t]{2}{*}{$\begin{array}{l}\text { Need } \\
\text { school } \\
\text { exam }\end{array}$} & $\begin{array}{l}\text { Communica- } \\
\text { tion University } \\
\text { of China }\end{array}$ & $\begin{array}{l}\text { Interview } 1 \text { Self-introduction (Chinese and English } \\
\text { optional) } 2 \text { Answer The examiner asks questions, } \\
\text { personally examines the examinee's professional } \\
\text { interests, communication skills, } 3 \text { expertise displays, } \\
\text { shows candidates in the computer, art, music, litera- } \\
\text { ture, film and television, participate in or organize } \\
\text { school activities, etc. Expertise, personal creative } \\
\text { works or related certificates. Proposition creation, } \\
\text { such as ereative design, computer-based production } \\
\text { programming, etc.; professional written examination } \\
\text { professional ability examination } 1 \text { aesthetic ability } \\
\text { examination } 2 \text { professional related fields basic } \\
\text { common sense examination } 3 \text { logical thinking and } \\
\text { innovative thinking ability examination: cultural } \\
\text { written examination, high school language, English, } \\
\text { mathematics. }\end{array}$ & $\begin{array}{l}\text { Provincial examinations and school exams must be } \\
\text { qualified. Cultural conversion ratio (= candidate's } \\
\text { college entrance examination results in the province } \\
\text { where the source of a score line): professional } \\
\text { conversion ratio (the total score of the university } \\
\text { entrance exam students in the province of profes- } \\
\text { sional qualified score line). The cultural conversion } \\
\text { ratio must be } 31 \text {, and it should be selected from the } \\
\text { highest to the lowest according to the ratio of } \\
\text { cultural conversion (line and line respectively). In } \\
2017 \text {, the total number of candidates for liberal arts } \\
\text { or liberal arts students does not exceed } 1 / 2 \text { of the } \\
\text { total number of professional programs (less than } 1 / 3 \\
\text { in } 2018 \text {. }\end{array}$ \\
\hline & $\begin{array}{l}\text { Jiangnan } \\
\text { University }\end{array}$ & $\begin{array}{l}\text { Distinguish between provincial exams and schoof } \\
\text { exams. Individual provinces may choose provin- } \\
\text { cial exams instead of participating in provincial } \\
\text { and university exems: arts examinations in the } \\
\text { province; sketches ( } 250 \text { points), colors (250 } \\
\text { points), and basic design foundations (250 points) } \\
\text { (90 points), decoration ( } 80 \text { points), text or graphic } \\
\text { creativity (80 points) }\end{array}$ & $\begin{array}{l}\text { Provincial entrance examination admission principle: } \\
\text { comprehensive score = professional provincial exam- } \\
\text { ination achievement cultural achievement. School } \\
\text { entrance examination results: comprehensive results } \\
\text { ( } 40 \% \text { or } 60 \% \text { of professional school results), culture } \\
\text { and professional schools are based on the full score } \\
\text { of } 750 \text { points. According to the total number of points } \\
\text { selected for admission, arts and science do not sort } \\
\text { separately. }\end{array}$ \\
\hline \multirow{2}{*}{$\begin{array}{l}\text { Cancel } \\
\text { school } \\
\text { exam }\end{array}$} & $\begin{array}{c}\text { Tongji } \\
\text { University }\end{array}$ & $\begin{array}{l}\text { Candidates' scores have resched the provincial } \\
\text { undergraduate qualifying score line, and obtained } \\
\text { the arts and professional provincial examination } \\
\text { certificate. The content of the National Arts } \\
\text { Examinations is roughly based on the modeling } \\
\text { basis and the color basis. The time for each } \\
\text { division is } 3 \text { hours, and the total score is } 300 \\
\text { points, with a score of } 150 \text { points per subject. }\end{array}$ & $\begin{array}{l}\text { Composite score }=\text { (major test scores / full scores of } \\
\text { professional examinations] } \times 400 \text { (college entrance } \\
\text { examination score / college entrance examination } \\
\text { culture full score) } \times 600 \text {, the total score of arts and } \\
\text { sciences in provinces from high to low, selected } \\
\text { meritorious admission }\end{array}$ \\
\hline & $\begin{array}{l}\text { Beijing Universi- } \\
\text { ty of posts and } \\
\text { Telecommunica- } \\
\text { tions }\end{array}$ & $\begin{array}{l}\text { Must participate in the provincial examination of } \\
\text { arts, and the provincial level examination results } \\
\text { must be higher than the local arts provincial } \\
\text { examination line of } 40 \text { or more to apply for our } \\
\text { school. For arts province examination does not } \\
\text { distinguish between undergraduate and special } \\
\text { line, examinee must be higher than arts province } \\
\text { examination qualified line } 80 \text { points and above } \\
\text { can apply for our school. Cultural achievement } \\
\text { needs to reach the provincial score line (2018 } \\
\text { provinces to make corresponding reforms, requir- } \\
\text { ing the division of different provinces and areas to } \\
\text { define a higher score) }\end{array}$ & $\begin{array}{l}\text { Candidates whose grades in the culture course of } \\
\text { the college entrance examination have reached the } \\
\text { entry control line and above of the art equivalent } \\
\text { undergraduate course in the province in which the } \\
\text { examinee is located, According to the college } \\
\text { entrance examination culture course actual exam- } \\
\text { ination result from high to low selected meritori- } \\
\text { ous candidates (arts and science department } \\
\text { together), according to the actual enrollment plan } \\
\text { number, determine the list to be admitted. }\end{array}$ \\
\hline
\end{tabular}


According to "Table II", Communication University of China and Jiangnan University still retain the examination method, while Beiyou and Tongji University will cancel the examination. The digital media professional recruiting students of Communication University of China makes full use of the independent recruiting students form of the school examination [7]. In addition to the basic examination and college entrance examination, the examinees must also pass the professional interview and professional examination of the school independent proposition, not only examine the students' ability to study and build, but also to the students' professional potential, innovation and The ability of communication and communication has been inspected in all directions. In the way of admission, on the basis of the achievement of cultural and professional courses, the ratio of cultural conversion (according to art and science respectively) is chosen from high to low. The Communication University of China converts the scores of major and culture to the corresponding qualified scores. In the aspect of recruiting students, the differences of college entrance examination in arts and science are taken into account. The examinees of arts and science are ranked separately. The students of arts have paid more attention to the logical reasoning ability of science students from less than $1 / 2$ of the total plan number before to $1 / 3$ at present.

Jiangnan University combined with its own design professional strengths, the fixed content of the examination in the school to do a small range of adjustments, the introduction of innovative design this examination content, in order to focus on students' modeling ability, focus on the innovative design ability; In the way of admission, different provinces can be divided into two models: provincial examination and school examination. In the provincial examination model, the total scores are combined according to the simple sum of the cultural courses and the results of the general examination. However, the total score of cultural courses is 750 , while the total score of specialized courses is only 300 , which is essentially a decrease in the proportion of professional courses. In the school examination model, the total score of culture courses and school examinations is 750 , and the total score is calculated according to $6: 4$ of both. Whether there is a school examination or not, Jiangnan University attaches more importance to the academic and logical ability of cultural courses.

Tongji University and Beijing University of Posts and Telecommunications, in accordance with the characteristics of their engineering colleges and universities, in the case of the art examination and the school examination content are similar, directly cancel the school examination, the main test results. In terms of admission methods, Tongji University converts the total scores of major courses and the total scores of cultural courses into equivalent points through certain calculation methods, multiplying them by different proportions and then adding them together. This method of calculation is more scientific than direct addition (because of the difference between the test scores of each region), the total score is the conversion ratio of the general examination result and the culture course result is $2: 3$, and the emphasis of the examination lies in the learning ability of the basic knowledge. Ability with logical reasoning.

The Beijing University of posts and Telecommunications, according to its position as a university of science and technology, only takes the arts examination pass as the basic threshold for applying for the university. Under the premise that the academic results of the provincial professional and cultural courses are over the line, the universities are accepted in the order of cultural achievements. Taking the cultural achievement as the final admission criterion, it can be seen that the students attach importance to their basic knowledge and logical reasoning ability.

In contrast, Communication University of China makes the best use of the autonomy of the examination, and independently selects qualified personnel to adapt to the professional abilities of the university according to its professional characteristics; the digital media major of Beijing University of posts and Telecommunications highlights the characteristics of engineering colleges and universities, and cancels the examination. Downplay art skills test scores, pay more attention to the requirements of learning ability. All the four universities are aware of the problem that the ability of the major students is not in accordance with the training goal, and then they think and explore four kinds of reform directions.

\section{REFORM DIRECTION OF RECRUITING STUDENTS SYSTEM FOR DIGITAL MEDIA SPECIALTY IN COLLEGES AND UNIVERSITIES}

To sum up, the development of recruitment students system is a dynamic process of spiral rising under the background of industry and academic driving discipline construction. The early art design adopted the College entrance examination of Arts to meet the needs of the industry at that time and to recruit students with painting ability. However, with the development of social culture and education, the development of science and technology, especially the development of digital information technology, students majoring in digital media should not only possess the ability of artistic design, but also have the ability of computer technology and image processing. The essence of examination is the means of talent selection. The development of industry and academic theory determines what kind of ability structure the examinee should have. Using this as the baton of the recruiting students mode to find talents who match the target ability, the author summarizes the factors associated with the recruiting students approach as shown in Figure 4.

Based on the above discussion, there is no difference in the selection logic behind the recruiting students mode of digital media major in Chinese and American universities. Except for the fact that the public universities in China are led by the government education department, the other related factors in the above table can be used generally. Therefore, each school type is different, want to cultivate talented person with which ability, should develop the corresponding training goal.The recruiting students method and the content of the test should be determined by 
combining the abilities expressed by the training objectives, rather than copying the recruiting students model of other colleges and universities[8]. The nature of private institutions in the United States gives them a high degree of recruiting students autonomy, although there is no fixed standard to follow. However, the ability selection system behind it shows that the individualized selection method does not play down the test of candidates' professional skills, and at the same time, the examination of professional potential, professional interest and innovation ability is more comprehensive. China's colleges and universities are the national universities under the Ministry of Education [9]. The examination emphasizes fairness and carries certain social responsibility. The basic principle of recruiting students is the scientific and impartial selection of talents. However, the entrance examination of arts still remains at the examination level of traditional modeling skills. The general examination, the school examination has solidified into sketch, color, but the sketch, color examination is actually mainly a test of the examinee's basic modeling ability. Modeling ability and digital media required learning, innovation ability cannot be equated. Provincial unification examination is the threshold that the examinee of digital media major must pass. The purpose of the examination is to screen the students with the ability of modeling in a primary way, which limits the scope of the recruiting students of the digital media major in disguise. The rigidity and cure of the examination content have not been able to study the professional skills and innovation ability of digital media professional students, and even lead to various social phenomena such as the hot of art examination.

School examination is the embodiment of the right granted by the Ministry of Education to the independent recruiting students of the school. Colleges and universities should make good use of this right and screen out the talents who really meet the goal of professional training. On the premise of fairness and justice, we should grasp the way of school examination as independent recruiting students and make corresponding reform according to the situation of our own school. The four universities of Communication University of China, Jiangnan University, Tongji University and Beijing University of posts and Telecommunications have all made corresponding reforms according to their own characteristics and for other colleges and universities to provide a great reference value. Under the present system, the Ministry of Education should weaken or cancel the provincial arts examination, and all colleges and universities should make full use of this tool, based on the goal and orientation of the selection of talents in colleges and universities in terms of examination content or total score calculation method. Make adjustments to suit your own characteristics. Therefore, colleges and universities should carry out the discussion and research on the objectives, characteristics and needs of talents training as soon as possible. On the basis of this, the author puts forward the orientation of talent selection ability so as to maximize the value of the independent recruiting students mode. More qualified students are selected to devote themselves to digital media arts, and to train high-quality talents for the society.

\section{CONCLUSION}

Digital media art, as a new specialty, under the background of the development of science and technology and the enrollment expansion of college students, it is still unable to meet the requirements of industry and academic development for students' ability according to the past "College entrance examination of Arts". This paper analyzes the origin and evolution of the "College entrance examination of Arts" system used by digital media major, and finds that its essence is the logic of talent ability selection, and the key is the matching degree between ability and specialty. The establishment of a discipline must depend on the corresponding knowledge system, and the construction and development of a major must be guided by the corresponding social industrial demand. The development of industry, the construction of disciplines and the characteristics of schools determine the training objectives of colleges and universities, and determine the differences of recruiting students strategies for specialties. Students who have the ability to match the industry demand and academic research direction in the present and future periods are selected through the corresponding examination content .The development of recruiting students is a process of dynamic change, which requires colleges and universities to constantly adjust their direction in order to adapt themselves to the requirements of talent quality and ability structure in the times. Efforts will be made to guide the overall improvement of the quality of talents and the training of innovative talents.

\section{REFERENCES}

[1] National Standards for Teaching Quality of Animation, Digital Media Art, and Digital Media Technology in 2018

[2] Ding Youdong. "Embrace new technologies is an inevitable choice for the cultivation of innovative talents in digital media arts" [J]. Art Education, 2018.02:12

[3] Yuan Xiyang. "Study on the Development of Chinese Art Design Education" [M]. Beijing Institute of Technology Press, Beijing, 2003: 20

[4] Li Yanzu. The Way of Design - The Formation and Development of Chinese Design Theory in the 20th Century[J]. Journal of Nanjing Arts University. 2008, 3:48-52.

[5] Xiao Yongliang. Development of digital media in the United States [J]. Computer Education, 2006, 5:47-50.

[6] Qin Chunhua, Lin Li. College entrance examination reform and comprehensive quality evaluation [J]. Chinese University Teaching, 2015.5:2-5

[7] Xie Chongqiao. "Design Designer / Comparative Study of Art Design Education between China and Finland" [M]. China Light Industry Press, 155-163.

[8] Li Xiangqi. Standards without a fixed standard - A review of the diversity of admission standards for well-known American universities. [J]. International Perspectives, 2004, 4 (3): 42-45.

[9] Zheng Ruoling. Dilemma and Breakthrough in the College Entrance Examination Reform[J]. Journal of Xiamen University (Philosophy and Social Sciences), 2017, 3:2-5. 